\title{
A new method to quantify atmospheric Poaceae pollen DNA based on the trnT-F cpDNA region
}

\section{Atmosferik Poaceae polen DNA miktarını belirlemek için trnT-F cpDNA bölgesini temel alan yeni bir metot}

https://doi.org/10.1515/tjb-2018-0020

Received January 16, 2018; accepted March 13, 2018; previously published online August 3, 2018

\section{Abstract}

Background: Pollen, mold spores, bacteria and viruses are the main biological substances in the atmosphere causing allergic symptoms and disease. Distinguishing pollen and spores is quite time consuming and requires a trained expert. There is a different approach to identification of these substances such as microscopic analysis. However, DNA based identification of these is becoming popular recently.

Objective: We evaluated the correlation between the quantity of DNA, which was amplified using trnT-F cpDNA specific primers in samples obtained from a high volume air sampler (HVAS), and concentration of Poaceae pollen collected with a Burkard trap.

Materials and methods: Here, we present a method for identifying and quantifying airborne Poaceae pollen using a single step polymerase chain reaction (PCR) technique.

\footnotetext{
*Corresponding author: Şenol Alan, Zonguldak Bulent Ecevit Universitesi, Biology, Zonguldak, Turkey, e-mail: palynology@gmail.com.

https://orcid.org/0000-0003-4941-1794

Tuğba Sarışahin and Ayşe Kaplan: Zonguldak Bulent Ecevit Universitesi, Biology, Zonguldak, Turkey, e-mail: tsarisahin@gmail.com (T. Sarışahin); ay414kaplan@hotmail.com (A. kalpan)

Aydan Acar Şahin and Nur Munevver Pınar: Ankara University, Biology, Ankara, Turkey, e-mail: aydanacar24@gmail.com (A.A. Şahin); pinar@science.ankara.edu.tr (N.M. Pinar). https://orcid.org/0000-0002-5350-5534 (A.A. Şahin) Ibrahim Erdoğan: Ahi Evran University, Department of Agricultural Biotechnology, Kirsehir, Turkey, e-mail: ibrhmerdgn@gmail.com
}

Forty daily air samples were collected by HVAS. The method was optimised using two different methods (M1 and M2) and the trnT-F cpDNA region was amplified using a Poaceae specific primer pair. The correlation between the quantity of DNA and pollen concentration was tested using R statistical programming language.

Results: Although a significant correlation was obtained between the M1 and M2 methods $\left(R^{2}=0.655, p<0.01\right)$, the M2 method was more correlated with pollen concentration. The correlation between pollen and DNA content changed due to episodes that were observed during the pollen season. DNA concentrations from the PCR data were significantly correlated with pollen concentrations determined by light microscopy $\left(R^{2}=0.767, p<0.01\right)$ in episode II using the M2 method and during the entire season $\left(R^{2}=0.469, \mathrm{p}<0.01\right)$ using $\mathrm{M} 2$.

Conclusions: The M2 method correctly identified Poaceae pollen in mixed air samples from Zonguldak Province. The non-coding trnT-F cpDNA region was used for the first time in aerobiological samples to identify Poaceae pollen. Use of this method that does not require DNA extraction may be a crucial step for real-time pollen monitoring devices to be developed in the future. The correlation strength between pollen and amplified DNA content could be improved using a sampler that has a lower absorption rate, and a more sensitive technique, such as qPCR.

Keywords: PCR; Pollen identification; trmT-F region; DNA quantity; Poaceae.

Öz

Amaç: Atmosferdeki polen, küf sporları, bakteriler ve virüsler alerjik semptomlara ve hastalıklara neden olan 
temel biyolojik maddelerdir. Polen ve sporların ayırt edilmesi oldukça zaman almakta ve eğitimli uzman gerektirmektedir. Bu maddelerin teşhisi için mikroskobik analiz gibi farklı yaklaşımlar bulunmaktadır. Bununla beraber, son zamanlarda bunların DNA temelli teşhisi popüler hale gelmiştir. Bu çalışmada Yüksek hacimli hava örnekleyicisinden (HVAS) elde edilen örneklerde trnT-F cpDNA'ya özgü primerler kullanılarak amplifiye edilen DNA miktarı ile Burkard tuzağ 1 ile toplanan Poaceae polen konsantrasyonu arasındaki korelasyon değerlendirildi.

Gereç ve Yöntem: Burada, tek aşamalı polimeraz zincir reaksiyonu (PCR) tekniği kullanılarak havadaki Poaceae poleni tanımlamak ve ölçmek için bir yöntem sunulmuştur. HVAS tarafından toplanan kırk günlük örneklerde, iki farklı yöntem optimize edildi ve trnT-F cpDNA bölgesi, Poaceae'ye özgü bir primer çifti kullanılarak çoğaltıldı. DNA ve polen konsantrasyonu arasındaki korelasyon, $R$ istatistik programlama dili kullanılarak test edildi.

Bulgular: M1 ve M2 yöntemleri arasında anlamlı bir korelasyon olmasına rağmen $\left(R^{2}=0,655, p<0,01\right)$, M2 yöntemi polen konsantrasyonu ile daha fazla ilişkiliydi. Polen ve DNA içeriği arasındaki korelasyon, polen mevsiminde gözlenen bölümler nedeniyle değişiklik göstermiştir. M2 yöntemi kullanılarak PCR verilerinden elde edilen DNA konsantrasyonları ile 1şık mikroskobu ile belirlenen polen konsantrasyonları arasında hem II. Bölümde $\left(R^{2}=0,767\right.$, $p<0,01)$, hem de tüm sezon boyunca $\left(R^{2}=0,469, p<0,01\right)$ önemli derecede ilişki bulunmuştur.

Sonuç: M2 yöntemi, Zonguldak ili atmosferinden elde edilen karışık örneklerdeki Poaceae polenlerinin doğru bir şekilde belirlemiştir. Kodlanmayan trnT-F cpDNA bölgesi ilk kez aerobiyolojik örneklerdeki Poaceae polenlerini belirlemek için kullanılmıştır. DNA özütlemesi gerektirmeyen bu metodun kullanımı ileride geliştirilecek eş zamanlı polen izleme cihazlarının önemli bir adım olabilir. Polen ve çoğaltılan DNA içeriği arasındaki ilişkinin kuvveti daha düşük emme kapasitesine sahip bir örnekleyici ve qPCR gibi daha hassas bir tekniğin kullanımıyla arttırılabilir.

Anahtar Kelimeler: PZR; Polen teşhisi; trnT-F bölgesi; DNA miktarı; Poaceae.

\section{Introduction}

Several biological substances, such as pollen, mold spores, parts of plants and animals and bacteria and viruses, can be found in air sample preparations [1]. Pollen and spores have been monitored in different parts of world for a long time. Atmospheric pollen and spore monitoring are widely used for aware sensitive individuals. Several studies have shown that the efficacy of immunotherapy increases, if it is started before the pollen season [2]. Pollen monitoring is also useful for estimating the start date for immunotherapy [3].

Methods to determine atmospheric content have been diversified throughout the last decade. Discriminating pollen and spores using a microscope is difficult and requires a trained staff. Therefore, there have been some attempts to determine pollen using image processing and molecular biological techniques [4]. Some studies have analysed allergens in samples collected with particle samplers using an enzyme-linked immunosorbent assay technique [5]. These studies have the advantage of directly determining substances that cause allergy using other than the traditional microscopic analysis. However, allergens are contained on some particles, such as starch granules, which are generally smaller than $1-2 \mu \mathrm{m}$ and released from pollen easily by altering humidity changes [6]. Because pollen and particles have different aerodynamic properties, there is an imbalance between pollen and allergen concentrations in the atmosphere. In some cases allergen levels were observed when no pollen grains were detected in the atmosphere [7].

Molecular techniques based on the polymerase chain reaction (PCR) have also been used to identify pollen DNA in the air. Müller-Germann et al. quantified Betula pollen in a DNA analysis using specific primer pairs for single-copy gene (BP8) and a multi-copy gene (internal transcribed spacer [ITS]) [8]. They used qPCR and DNA sequence analyses and obtained a strong correlation with pollen data taken from the COSMO-ART model system. In a more recent study, Juniperus pollen was measured in 105 air samples during 2013-2015 with qPCR and species-specific primers and probes. The correlation between pollen and DNA content was very high $\left(\mathrm{R}^{2}=0.902\right)$ [9]. Variability in the ITS sequence has also been used to quantify DNA in mugwort and ragweed [10]. These techniques are also useful for determining long distance transported pollen, because pollen in the air can be identified at the species level, whereas the genus or family level is most commonly used in microscopic analyses. Using matK-specific primers, it was confirmed that some Juniperus pollen observed in the Tulsa atmosphere originated from J. ashei transported from South Oklahoma and Texas to Canada [11]. Leontidou et al. reported that the chloroplast $t r n \mathrm{~L}$ gene region can be used to identify pollen. That study differentiated Juniperus and Poaceae family samples with different complexities [12].

Although detection of pollen to the species level is appropriate for systematic purposes, scalability on detection of pollen in the atmosphere is more important to represent the allergenic load for sensitive individuals. Pollen allergens generally have conserved sequences. Therefore, 
pollen of systematically related species often cross-react. Some individuals who are sensitised to pollen can show allergic reactions against some foods [13]. Because crossreactivity is common among Poaceae pollen, grass pollen mix is generally used to diagnosis of allergy. Hence the region to be amplified should allow scalability of pollen identification either at the species and family levels.

The non-coding trnT-F cpDNA region includes three highly conserved tRNA genes. However, the spacers separating these genes are highly variable and help determine the relationships at the species and genus levels $[14,15]$. The spacer region consists of several hundred base pairs. Other studies have used the trnT-F cpDNA region to investigate the phylogeny of some families and orders [16-18]. This region is also useful for identifying complex mixes of plants in complex mixes. Wallinger et al. used a trnT-F cpDNA specific primer to identify the plant species eaten by insect larvae [19].

In this study, we determined the correlation between the quantity of DNA amplified using trnT-F cpDNA specific primers and Poaceae pollen concentration. We also carried out optimisation of the DNA quantification method in the samples from a High Volume Air Sampler (HVAS), which contains higher amount of abiotic and biotic particles than those of traditional pollen and spore samplers.

\section{Materials and methods}

\section{Collection of atmospheric samples and pollen materials}

We analysed 40 daily air samples collected by a HVAS placed on the roof of a building in Zonguldak during 13 May18 June in 2016. The sampler directs air that is suctioned in from the atmosphere $(900 \mathrm{~L} / \mathrm{min})$ onto polyurethane filters placed in cascades. The sampler is equipped with two cascades. The upper cascade collects the particles which size of particulate matter (PM) is bigger than $10 \mu \mathrm{m}$, whereas the bottom cascade holds those of $10 \mu \mathrm{m}>\mathrm{PM}>2.5 \mu \mathrm{m}$. The filters were changed daily at 12:00.

Poaceae pollen was collected using a Burkard 7-day pollen and spore trap. The trap was operated at $10 \mathrm{~L} / \mathrm{min}$. Daily pollen amount was counted in the entire full area and expressed as pollen $/ \mathrm{m}^{3}$.

Phleum pratense L. and Setaria viridis (L.) P. Beauv. pollen from Zonguldak were collected and used as a positive control. Betula pendula Roth and Ambrosia artemisiifolia L. pollen which collected from Artvin and Düzce and an atmospheric sample that belongs to on the date of 20
February were used as negative controls. A small amount of pollen from both control groups was directly added to the PCR mix, according to manufacturer's instructions.

\section{Extraction of filters and condensation of extracts}

Only the upper filters (PM $>10 \mu \mathrm{m})$ were used in this study. The filters were cut into three equal parts before extraction. Two filter parts were extracted separately in ammoniumbicarbonate buffer (pH 8.1) and were aliquoted into $5 \mathrm{~mL}$ vials. Two different extraction methods (M1 and M2) were used for optimisation. Some of the vials was directly lyophilised (M1), whereas other vials were clarified by centrifugation at $6000 \times \mathrm{g}$ for $10 \mathrm{~min}$ before lyophilisation (M2).

\section{PCR and DNA quantification}

The PCR experiment was carried out using Plant Direct Kit (Thermo Scientific, Waltham, MA, USA). Before PCR, the vials were resuspended in phosphate buffered saline. A $1 \mu \mathrm{L}$ sample was directly used as the DNA template. The trnT-F cpDNA region was amplified using a Poaceae specific primer pair [19] (Table 1). The PCR reactions were performed on the T100 thermal cycler (BioRad Laboratories, Hercules, CA, USA). The following program was used for the PCR reactions: after a $2 \mathrm{~min}$ initial denaturation at $94^{\circ} \mathrm{C}, 40$ cycles of $20 \mathrm{~s}$ at $95^{\circ} \mathrm{C}, 1 \mathrm{~min}$ at $50.5^{\circ} \mathrm{C}$ and $1 \mathrm{~min}$ at $72^{\circ} \mathrm{C}$, followed by $2 \mathrm{~min}$ at $72^{\circ} \mathrm{C}$.

The amplified DNA fragments were quantified using the Qubit ${ }^{\circledR}$ dsDNA HS Assay Kit (Life Technologies, Foster City, CA, USA) on a Qubit ${ }^{\circledR}$ 2.0 Fluorometer (Life Technologies). Briefly, $1 \mu \mathrm{L}$ of each sample was added to a microcentrifuge tube as part of the High Sensitivity DNA kit. After a 2 min incubation, the amount of DNA was measured. Agarose gel (2\%) electrophoresis was used to confirm replication and verify a single amplified band.

\section{Statistical analysis}

Spearman's rank order test and a non-parametric correlation analysis were used to determine the relationship

Table 1: List of Poaceae-specific primers used in the polymerase chain reaction analysis.

\begin{tabular}{ll}
\hline Primer name & Primer sequences $\left(5^{\prime}-3^{\prime}\right)$ \\
\hline Poa-gen-S541 & GCTTTCTCATTCTACTCTTTC \\
Poa-gen-A551 & CTTTTCTTGTGCATCATCCTAG \\
\hline
\end{tabular}


between pollen and the quantity of DNA using R statistical programming language [20]. A p-value $<0.05$ was considered significant.

\section{Results}

The total pollen index during the pollen season was 1442. The peak day of Poaceae pollen was 30 May (12.4 pollen $\left./ \mathrm{m}^{3}\right)$. Three distinct episodes were observed during the pollen season of 2016 in Zonguldak. The majority of the pollen was observed in episode II. A positive correlation was obtained separately for these episodes using both methods. The strength of the correlation both methods was higher than that of the total season (Table 2).

The specificity of the primer pairs was tested against the positive controls (P. pratense, S. viridis, 13 May and 21 May samples) and negative controls (B. pendula, A. artemisiifolia and 20 February sample) groups (Figure 1). The PCR results revealed one DNA band at $252 \mathrm{bp}$ as the positive control.

The two preparation methods were also tested to optimise the results. The method in which the samples were clarified by centrifugation (M2) was the most effective. Although it varied depending on the method used for extraction, total DNA quantities were differed between $1.71 \times 10^{5}$ and $1.97 \times 10^{5}$. Despite that a higher total DNA content was obtained with the M1 method and the two methods were correlated $\left(R^{2}=0.655, p<0.01\right)$, a positive correlation was only observed between pollen and DNA content with the M2 method $\left(\mathrm{R}^{2}=0.469, \mathrm{p}<0.01\right)$ (Table 2$)$.

\section{Discussion}

It is a new challenge to determine atmospheric pollen content using molecular biological techniques. Several studies have identified and quantified pollen in atmospheric samples based on DNA content. Many gene regions have been used for this purpose. This is the first time that optimised PCR assays based on trnT-F cpDNA specific primers have been used to identify Poaceae pollen DNA, were used by this study. Müller-Germann et al. analysed air filter samples by qPCR using two different primer pairs (BP8 and ITS). They reported a high correlation coefficient $\left(\mathrm{R}^{2}=0.92\right)$ between the quantity of DNA and pollen levels of the COSMO-ART model system [8]. In another study, matK specific primers were used to identify Juniperus pollen in 105 air samples collected with a Burkard spore trap. A significant correlation was found between pollen concentrations determined by qPCR and those collected with the Burkard pollen and spore trap $\left(\mathrm{R}^{2}=0.902\right)$ [9]. They used a Hirst type pollen sampler, which is similar to the Burkard. The correlation between pollen and quantity of DNA was also high, as in other studies [12].

We obtained a relatively lower correlation than these studies, which may be related to using different samplers for collecting pollen and DNA containing particles. Mohanty et al. used samples from a single sampler for both microscopic and DNA analyses [9]. The sampler used to perform the DNA analysis has been used for the pollen

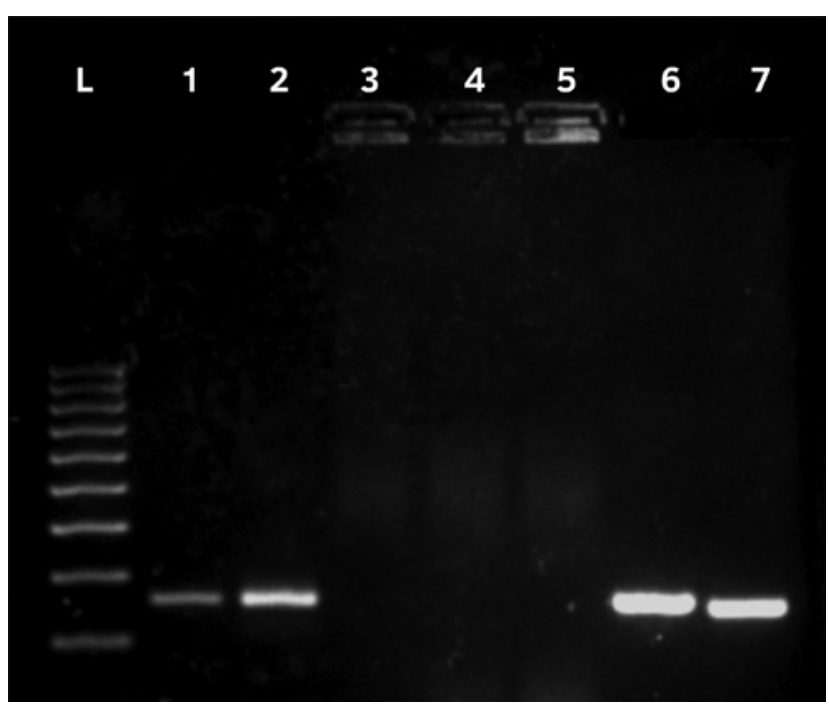

Figure 1: Agarose gel view of the control groups.

(L) DNA ladder (100-1000 bp), (1) 13 May sample, (2) 21 May sample, (3) 20 February sample, (4) A. artemisiifolia pollen, (5) B. pendula pollen, (6) S. viridis pollen, (7) P. pratense pollen.

Table 2: Results of the correlation analysis between pollen and quantity of DNA obtained by two methods.

\begin{tabular}{|c|c|c|c|c|c|}
\hline & \multirow[t]{2}{*}{ Pollen level (pollen grains $/ \mathrm{m}^{3}$ ) } & \multicolumn{2}{|r|}{ M1 } & \multicolumn{2}{|r|}{$M 2$} \\
\hline & & Corr. & DNA content & Corr. & DNA content \\
\hline Total & 98.8 & 0.122 & $1.97 \times 10^{5}$ & $0.469^{b}$ & $1.71 \times 10^{5}$ \\
\hline Episode I (13-17 May) & 17.7 & -0.7 & $9.46 \times 10^{3}$ & -0.1 & $1.23 \times 10^{4}$ \\
\hline Episode II (20 May-06 June) & 55.4 & $0.491^{\mathrm{a}}$ & $4.67 \times 10^{4}$ & $0.767^{\mathrm{b}}$ & $6.71 \times 10^{4}$ \\
\hline Episode III (13-20 June) & 25.7 & 0.083 & $5.83 \times 10^{4}$ & 0.598 & $6.53 \times 10^{4}$ \\
\hline
\end{tabular}

${ }^{a}$ Correlation is significant at the 0.05 level (2-tailed). ${ }^{b}$ Correlation is significant at the 0.01 level (2-tailed). 


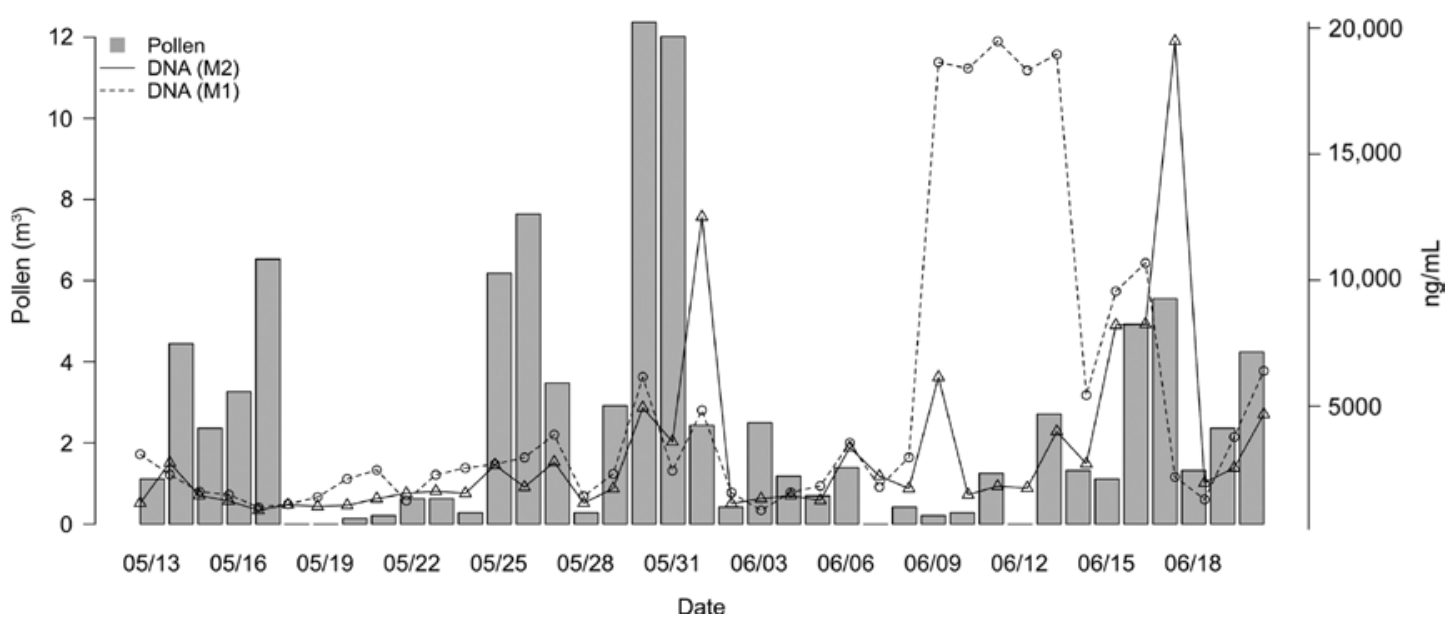

Figure 2: Changes in Poaceae pollen and DNA content amplified using a Poaceae-specific primer pair on filters containing the size of PM is bigger than $10 \mu \mathrm{m}$.

count in many studies [21, 22]. We used a fluorometer to quantify the DNA different from other studies of which were used qPCR which allow more accurately DNA quantification. This could be another reason why a lower correlation was observed between Poaceae pollen and the quantity of DNA in this study. According to correlation results of the two methods, centrifugation has positive effect on the correlation between pollen concentration and the quantity of DNA in the M2 method (Figure 2). Hence, the higher particulate content in the air samples due to the high suction rate of the sampler may have decreased the strength of the correlation (Table 2).

Pollen season in Zonguldak appears not to be homogenous. We obtained comparable results from other studies at the level of episodes using both methods. In particular, high DNA content was obtained by the two methods during episode III. DNA extraction from plants is harder than that from other biological samples because of the cell wall. However, pollen has an opening on the surface called the aperture. The aperture plays a key role in pollen tube germination and allows the release of pollen by a simple force, such as centrifugation. Hence, centrifugation, as part of the M2 method, could have helped extract DNA from the pollen, whereas the M1 method may have increased DNA content by including other Poaceae plant parts sucked by the sampler. The highest concordance $\left(\mathrm{R}^{2}=0.767, \mathrm{p}<0.01\right)$ between the quantity of DNA and pollen count was observed in episode II with the M2 method.

On the other hand, lower DNA content than pollen concentration during episode I may be an indicator of pollen transportation. As mentioned above, pollen is easily released into the air by changes in humidity level. Therefore, pollen captured by the Burkard sampler in episode I may have already released DNA during transport.
Although identifying pollen at the species level can be useful to demonstrate long distance pollen transport, it does not represent the allergenic load to sensitive patients. The majority of pollen allergens have conserved sequences, so polysensitisation to systematically related pollen is very common in a sensitive patient [23]. Thus, scalability in determining DNA-based pollen should be a top priority. We cannot describe a Poaceae allergy by looking at a single Lolium perenne $\mathrm{L}$. or P. pratense pollen grain in the air. We should look at the genus or family level according to necessity. The trnT-F cpDNA region was useful in the present study to identify Poaceae pollen. The next generation sequencing method, such as metabarcoding, has been used to identify pollen at the species and family levels [21, 22]. However, the next-generation sequencing is expensive and time consuming.

Another advantage of our method is that it is not a necessary step of DNA extraction due to the kit used for DNA amplification. On the other hand, a sampler such as the Burkard, which is changed weekly, may not be suitable for real-time monitoring. Impactor samplers with multi-vials may be appropriate for this purpose. The use of a method that does not require DNA extraction may be a crucial step toward real-time pollen monitoring devices developed in the future.

As a result, it was shown here that the trnT-F cpDNA intergenic spacer region is very useful for quantifying atmospheric Poaceae pollen DNA at the family level. The necessity of the centrifugation step in the present method depends on whether the content of the other particles is higher than the pollen due to the sampler absorption rate. Thus, the use of different samplers, such as a low-volume air sampler, and a more sensitive quantifying technique, such as qPCR, will allow for the direct determination of 
atmospheric pollen faster than any other method in the literature and will be free from this requirement.

Acknowledgements: This research was partly supported by the Scientific and Technological Research Council of Turkey (TÜBİTAK), Grant No: KBAG-113Z762.

\section{References}

1. Ceter T, Pınar NM, Alan Ş, Yıldırım Ö. Polen ve sporların haricinde atmosferde bulunan allerjen biyolojik partiküller. Asthma Allergy Immunol 2008;6:5-10.

2. Horak F, Jaeger S, Worm M, Melac M, Didier A. Implementation of pre-seasonal sublingual immunotherapy with a five-grass pollen tablet during optimal dosage assessment. Clin Exp Allergy 2009;39:394-400.

3. Creticos PS, Esch RE, Couroux P, Gentile D, D'angelo P, Whitlow $B$, et al. Randomized, double-blind, placebo-controlled trial of standardized ragweed sublingual-liquid immunotherapy for allergic rhinoconjunctivitis. J Allergy Clin Immunol 2014;133:751-8.

4. del Pozo-Baños M, Ticay-Rivas JR, Cabrera-Falcón J, Arroyo J, Travieso-González CM, Sánchez-Chavez L, et al. Image processing for pollen classification. In: Biodiversity Enrichment in a Diverse World. Intech 2012.

5. Buters JT, Thibaudon M, Smith M, Kennedy R, Rantio-Lehtimäki A, Albertini R, et al. Release of Bet $v 1$ from birch pollen from 5 European countries. Results from the HIALINE study. Atmos Environ 2012;55:496-505.

6. Suphioglu C. Thunderstorm asthma due to grass pollen. Int Arch Allergy Immunol 1998;116:253-60.

7. Plaza MP, Alcázar P, Hernández-Ceballos MA, Galán C. Mismatch in aeroallergens and airborne grass pollen concentrations. Atmos Environ 2016;144:361-9.

8. Müller-Germann I, Vogel B, Vogel H, Pauling A, Fröhlich-Nowoisky J, Pöschl U, et al. Quantitative DNA analyses for airborne birch pollen. PLoS One 2015;10:e0140949.

9. Mohanty RP, Buchheim MA, Levetin E. Molecular approaches for the analysis of airborne pollen: a case study of Juniperus pollen. Ann Allergy Asthma Immunol 2017;118:204-11. e2.

10. Müller-Germann I, Pickersgill DA, Paulsen H, Alberternst B, Pöschl U, Fröhlich-Nowoisky J, et al. Allergenic Asteraceae in air particulate matter: quantitative DNA analysis of mugwort and ragweed. Aerobiologia 2017;33:493-506.

11. Mohanty RP, Buchheim MA, Anderson J, Levetin E. Molecular analysis confirms the long-distance transport of Juniperus ashei pollen. PLoS One 2017;12:e0173465.
12. Leontidou K, Vernesi C, De Groeve J, Cristofolini F, Vokou D, Cristofori A. DNA metabarcoding of airborne pollen: new protocols for improved taxonomic identification of environmental samples. Aerobiologia 2018;34:63-74.

13. Ebner C, Hirschwehr R, Bauer L, Breiteneder H, Valenta R, Ebner $\mathrm{H}$, et al. Identification of allergens in fruits and vegetables: IgE cross-reactivities with the important birch pollen allergens Bet v 1 and Bet v 2 (birch profilin). J Allergy Clin Immunol 1995;95:962-9.

14. Borsch T, Hilu KW, Quandt D, Wilde V, Neinhuis C, Barthlott W. Noncoding plastid trnT-trnF sequences reveal a well resolved phylogeny of basal angiosperms. J Evol Biol 2003;16: 558-76.

15. Okaura T, Harada K. Phylogeographical structure revealed by chloroplast DNA variation in Japanese beech (Fagus crenata Blume). Heredity 2002;88:322-9.

16. Bayer RJ, Starr JR. Tribal phylogeny of the Asteraceae based on two non-coding chloroplast sequences, the trnL intron and trnL/trnF intergenic spacer. Ann Mo Bot Gard 1998;85: 242-56.

17. Sauquet H, Doyle JA, Scharaschkin T, Borsch T, Hilu KW, Chatrou LW, et al. Phylogenetic analysis of Magnoliales and Myristicaceae based on multiple data sets: implications for character evolution. Bot J Linn Soc 2003;142:125-86.

18. Müller KF, Borsch T, Hilu KW. Phylogenetic utility of rapidly evolving DNA at high taxonomical levels: contrasting matK, trnT-F, and rbcL in basal angiosperms. Mol Phylogenet Evol 2006;41:99-117.

19. Wallinger C, Juen A, Staudacher K, Schallhart N, Mitterrutzner E, Steiner E-M, et al. Rapid plant identification using species-and group-specific primers targeting chloroplast DNA. PLoS One 2012;7:e29473.

20. $R$ Core Team. R: a language and environment for statistical computing. Vienna, Austria: R Foundation for Statistical Computing, 2013. http://www.R-project.org/. Accesssed: 26 December 2017.

21. Núñez A, de Paz GA, Ferencova Z, Rastrojo A, Guantes R, García $A M$, et al. Validation of the hirst-type spore trap for simultaneous monitoring of prokaryotic and eukaryotic biodiversities in urban air samples by next-generation sequencing. Appl Environ Microbiol 2017;83:e00472-17.

22. Kraaijeveld K, Weger LA, Ventayol García M, Buermans H, Frank J, Hiemstra PS, et al. Efficient and sensitive identification and quantification of airborne pollen using next-generation DNA sequencing. Mol Ecol Resour 2015;15:8-16.

23. Erkara IP, Cingi C, Ayranci U, Gurbuz KM, Pehlivan S, Tokur S. Skin prick test reactivity in allergic rhinitis patients to airborne pollens. Environ Monit Assess 2009;151:401-12. 